\title{
Modeling thermal and gas-dynamic processes in a steam turbine exhaust hood
}

Svitlana Alyokhina,

\section{Olha Simbirska}

A. N. Podgorny Institute for Mechanical Engineering Problems of the National Academy of Sciences of Ukraine, 2/10 Dm. Pozharsky Street, Kharkiv, UA-61046, Ukraine E-mail:alyokhina@ipmach.kharkov.ua
The operation safety of any turbo-installation depends on the effectiveness and reliability of working of its basic constructs. For that purpose it is required to use modern approaches to constructions of turbine equipment of the Thermal Power Station (TPS) and Heat Power Plant (HPP). It is impossible without a detailed investigation of thermal and gas-dynamic processes.

The investigations of thermal and gas dynamic processes in a steam turbine exhaust hood have been carried out. The numerical solving of the conjugate heat transfer problem was used. This approach allowed to define the thermal field of steam and solid case, and the velocity field of steam. These results of investigations will be used in solving inverse heat transfer problems for definition of heat transfer coefficients on inner surfaces of the exhaust hood.

Key words: steam turbine exhaust hood, conjugate heat transfer problem, thermal and gas-dynamic processes

\section{INTRODUCTION}

The operation safety of any turbo-installation depends on the effectiveness and reliability of working of its basic elements. For that purpose it is required to use modern approaches to constructions of turbine equipment of TPS and HPP. It is impossible without a detailed investigation of thermal and gas-dynamic processes.

The exhaust hood is a very important part of steam turbines. In particular the construction of the exhaust hood has a big influence on the economy and reliability of the turbine $[1,2]$. Its aerodynamic performances influence the economy of the turbine. During the operations the operating environment in the exhaust hood of the high pressure cylinder (HPC) has the complex structure and the walls of the exhaust hood are subjected to the temperature differences at changing of the turbine operating regime.

An important factor which influences the efficiency and durability of the exhaust hood is unevenness of electric load in the power grid. As a result, the number of turbine shutdowns and startups from different thermal conditions and work on low-consumption regimes has increased. In this case the steam flow rate decreases in comparison with the nominal regime.

The turbine work at low-consumption regimes can be dangerous for the exhaust hood casing because in this case large tangential flow twisting, redistribution of steam flow rate, angles of flow radial direction and the flow separation in the sleeve zone after the last turbine stage are possible.

This character of the vapor flow in the inlet of the exhaust hood essentially restructures the flow in the exhaust hood and forms the reverse flows along the root bounding surface.

This can change the rate of exhaust hood walls and flanges heating and increase the local thermal stresses.

So it is very important to make investigations of thermal and gas-dynamic processes in this turbine element. 


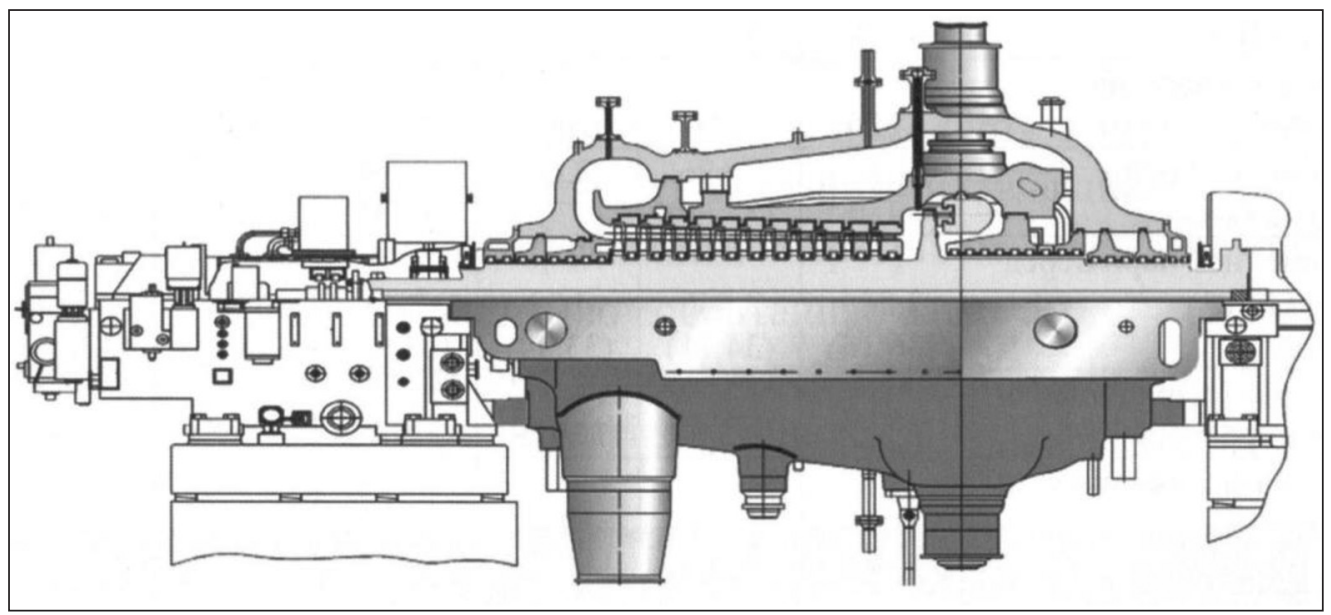

Fig. 1. The high-pressure cylinder of the turbine K-325-23.5

\section{PROBLEM DEFINITION}

Today the turbine K-325-23.5 of the joint-stock corporation "Turboatom" is one perspective project of the Ukrainian turbine construction industry [3]. It is necessary to make investigations for its reliability and long operation. The main part of these investigations is identifications of thermal and gas-dynamic processes in construct elements.

The high-pressure cylinder of the turbine K-325-23.5 is shown on Fig. 1. The exhaust hood has a toroidal form with two exhausts at the bottom. The exterior casing of HPC is covered by isolation. This fact was taken into account in thermal investigations.

Thermal and gas-dynamics processes were investigated on the nominal and underloading turbine regimes.

\section{METHODOLOGY OF SOLVING}

The test operation with complex objects like the exhaust hood of the steam turbine is a very difficult problem which is associated with risk of equipment damage and the high financial expenditure. The solution of this problem is computational modeling.

One of problems at investigation of thermal and gasdynamic processes is a problem of boundary conditions definition in zones where operation environment has contact with the metal casing. Taking into account the cooling of steam near the solid surfaces is also a problem. In this case effective instruments are the conjugate heat transfer problems which take into account the interference of heat transfer in the solid body and gas environment.

The mathematical model of the conjugate heat transfer problem consists of the following equations:

1) For gas environment:

- continuity equation (mass sources and sinks are absent):

$$
\frac{\partial \rho}{\partial \tau}+\operatorname{div}(\rho v)=0
$$

where $\rho$ is density of gas, $\mathrm{kg} / \mathrm{m}^{3} ; \tau$ is time, $\mathrm{s} ; v$ is the velocity vector, $\mathrm{m} / \mathrm{s}$;

- equation of motion of viscous gas:

$$
\rho \frac{d \mathrm{v}}{\partial \tau}=-\operatorname{grad}\left(p+\frac{2}{3} \mu_{e} \operatorname{div} \mathrm{v}\right)+2 \operatorname{div}\left(\mu_{e} \dot{\mathrm{S}}\right),
$$

where $p$ is static pressure, $\mathrm{Pa}$; $\mu_{e}$ is an effective coefficient of dynamic viscosity, $\mathrm{kg} / \mathrm{m} \cdot \mathrm{s}, \dot{\mathrm{S}}$ is a tensor of strain rates;

- energy equation:

$$
\frac{\partial}{\partial \tau}(\rho E)+\operatorname{div}(\mathrm{v}(\rho E+p))=\operatorname{div}\left(\lambda_{e} \operatorname{grad} T\right),
$$

where $E$ is total energy, carried to mass unit; $T$ is temperature, $\mathrm{K} ; \lambda_{e}$ is the heat conductivity coefficient (in consideration of the turbulent constituent), $\mathrm{W} /(\mathrm{m} \cdot \mathrm{K})$. In consequence of a small absolute value of the dissipative function there are not sources of heat here which were generated of the mechanical work of the gas flow.

2) For solid medium there is the equation of heat conduction (the Fourier equation):

$$
\operatorname{div}(\lambda \operatorname{grad} T)=c_{p} \rho \frac{\partial T}{\partial \tau},
$$

where $\lambda$ is the heat transfer coefficient; $T$ is temperature, $\mathrm{K}$; $c_{p}$ is the heat capacity of material, $\mathrm{J} / \mathrm{kg} \cdot \mathrm{K}$.

For closure of the differential equations system added to the equation of gas environment state there is dependence of the density of environment on temperature and pressure. For calculation of the turbulent components which were included into the equations of moving and energy the Menter's model of the shear stresses $k-\omega$ was used [4]. The physical characteristics in the equations were considered as functions of temperature and pressure in the working interval of temperatures. 


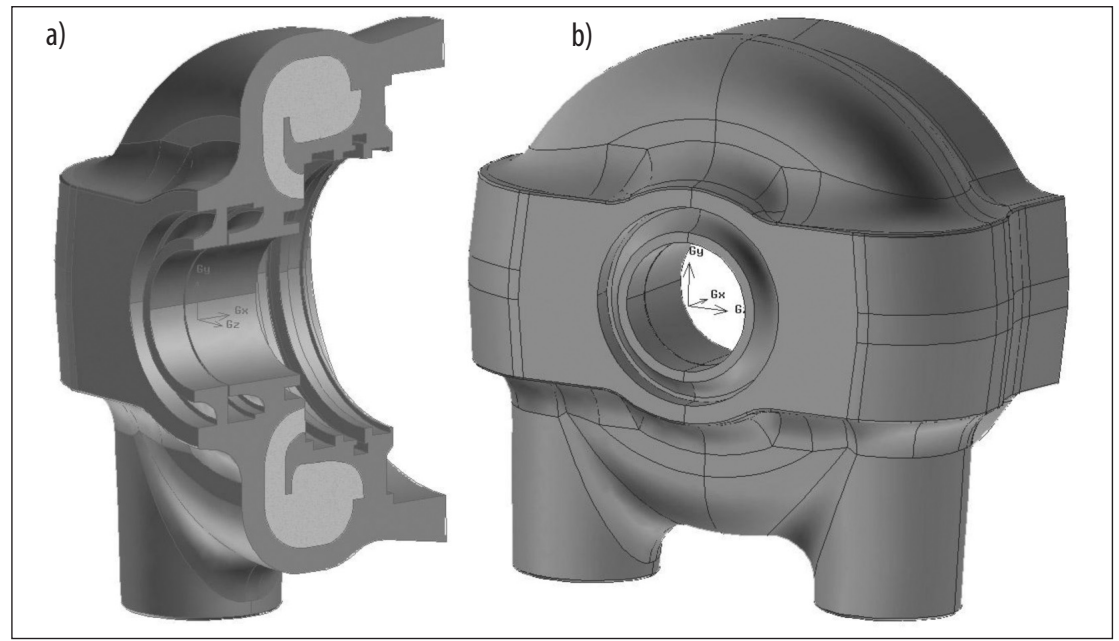

Fig. 2. The calculation area: a) the fragment of the calculation area; b) the complete area

A control-volume-based technique [5] is used for solving of the model equations.

The calculation area for the exhaust hood of HPC (Fig. 2) was realized in $3 \mathrm{D}$ mesh. The calculating mesh has more than 1.5 million nodes which allow to consider thermal and gas-dynamic processes and take into account flow specifics near the solid body.

The boundary conditions for the calculation of the exhaust hood model were accepted according to the thermal calculation of HPC for the exit section after the 12th stage rotor blades (Table).
The radial distribution of the steam parameters and values of axial and circumferential velocity components are assumed constant.

For velocity and temperature fields detecting the nominal regime was chosen. At this regime the steam flow rate was $\mathrm{Gt}=1000 \mathrm{t} / \mathrm{h}$. The regimes with $700,500,300 \mathrm{t} / \mathrm{h}$ flow rates were also considered.

For each considered operating regime a special fluid-velocity profile at the outlet from the 12th stage was formed. For example, for the nominal operating regime the fluid-velocity profile will have the form which is shown on Fig. 3.

\section{Table. Boundary conditions in the inlet of the exhaust hood}

\begin{tabular}{ccccc}
\hline Values & \multicolumn{3}{c}{ Regimes } \\
\hline $\mathrm{G}_{T^{\prime}}, \mathrm{t} / \mathrm{h}$ & 1000 & 700 & 500 & 300 \\
\hline $\mathrm{G}_{12}, \mathrm{~kg} / \mathrm{s}$ & 255.24 & 173.2 & 122.64 & 81.94 \\
\hline $\mathrm{P}_{3-12}, \mathrm{Mpa}$ & 4.14963 & 2.943 & 1.8639 & 1.169352 \\
\hline $\mathrm{T}_{3-12{ }^{\circ}}{ }^{\circ} \mathrm{C}$ & 283.7 & 270 & 257 & 0.1918 \\
\hline $\mathrm{V}_{3-12} \mathrm{~m}^{3} / \mathrm{kg}$ & 0.0575 & 0.07678 & 0.1100 & 61.87 \\
\hline $\mathrm{C}_{2 \prime} \mathrm{m} / \mathrm{s}$ & 55.47 & 49.97 & 50.49 & 58.66 \\
\hline $\mathrm{C}_{22} \mathrm{~m} / \mathrm{s}$ & 54.78 & 49.64 & 50.45 & -19.67 \\
\hline $\mathrm{C}_{2 u^{\prime}} \mathrm{m} / \mathrm{s}$ & -8.74 & 5.71 & 3.74 & 71.46 \\
\hline $\mathrm{a}_{2 \prime}$ degree & 80.94 & 96.56 & 94.25 & \\
\hline
\end{tabular}

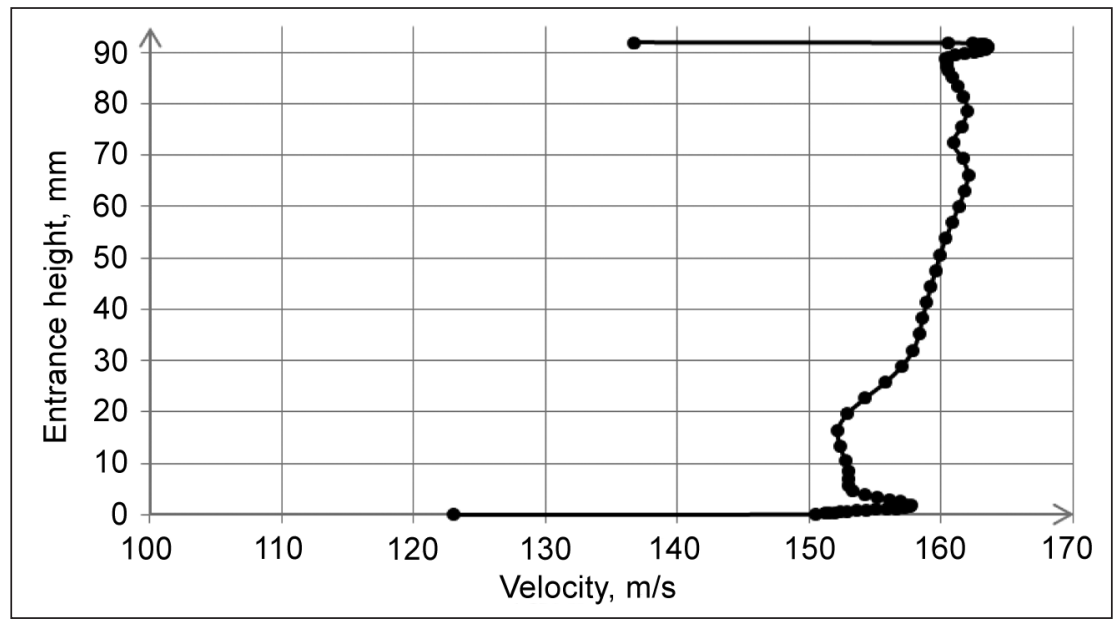

Fig. 3. The flow velocity in the inlet of the exhaust hood on the nominal operation regime $\mathrm{G}=1000 \mathrm{t} / \mathrm{h}$ 


\section{INVESTIGATION RESULTS}

The solution of the direct conjugate problem of heat transfer allowed defining the structure of flow in the exhaust hood of HPC (Fig. 4). This figure shows that after moving by the steam channel of HPC the flow goes to the cave of the exhaust hood where becomes twisted and after division goes to the bottom exhaust (Fig. 4a). The structure of the flow in the section placed in the plane $z 0 y$ shows the character of the steam moving lengthways of the inner surfaces of the exhaust hood (Fig. 4b). The small flow separation occurs near the exit of the diffuser (point 15) and near the zone where the casing and the iron ring are connected (points 9 and 10).

The steam velocity distribution (Fig. 5) in the exhaust hood influences the heat exchange conditions on its surfaces.

Researches have shown that for all considered turbine regimes the flow structure is similar.

In the toroidal camera the flow rate increases from section I-I to section IV-IV. In the bottom part of the exhaust hood the steam moves from section VI-VI to section $\mathrm{V}-\mathrm{V}$.

The solving of the conjugate heat transfer problem allows to define thermal field in the solid body and gas. The thermal field in the vertical section is shown on Fig. 6 . The high speed of gas causes the uniform temperature distribution in the inner cavity of the exhaust hood. The outer case of HPC have also warmed up uniformly, the highest temperature of metal being in the salient part (deflector).

According to the results of the numerical investigation, the operating regime change does not significantly affect the temperature distribution in the circumferential direction on the inner surface of the exhaust hood (Fig. 7).

The decreases of twisting flow influence at lower steam flow rate were detected and the flow rate became almost equal in both outlet tubes. So the flow structure relative to the vertical cross section is symmetric and in next investigations the calculation area can be considered as one symmetrical part.

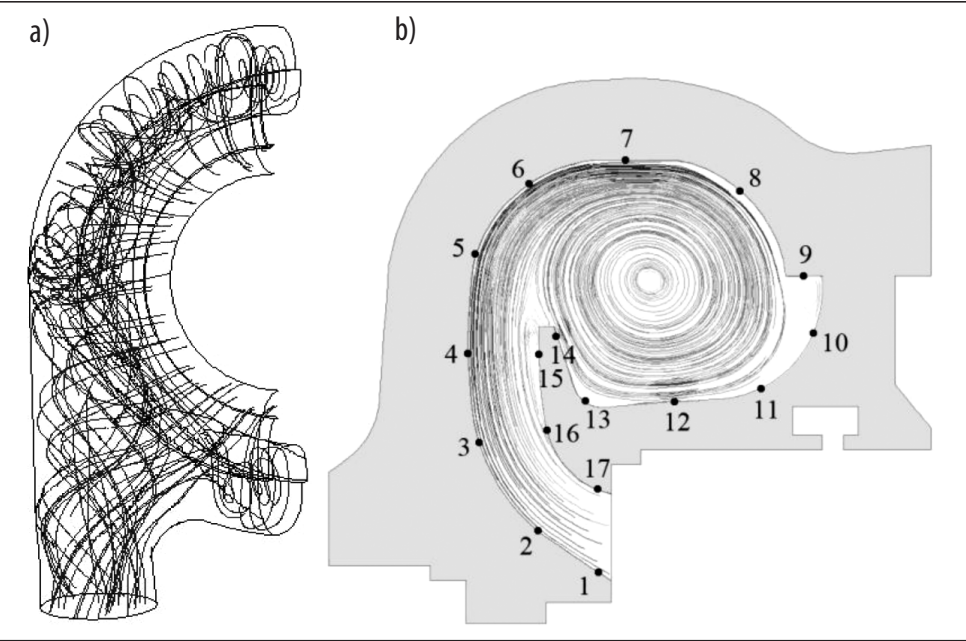

Fig. 4. The structure of flow in the exhaust hood of HPC: a) current streamlets for all calculation area; $b)$ current streamlets in the section placed in the plane $20 y$

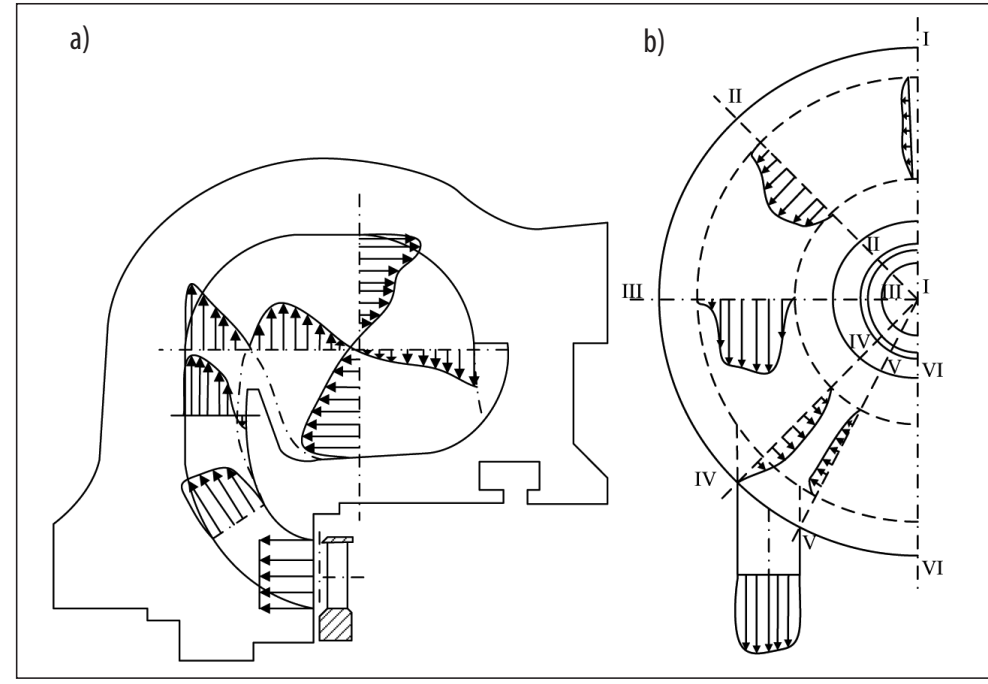

Fig. 5. The components of steam flow in the exhaust hood: a) circumferential component; b) flow rate component

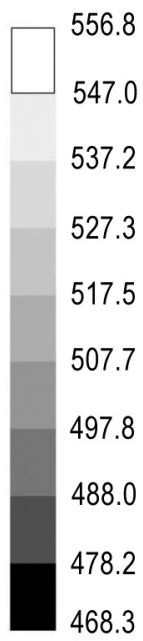

Fig. 6. The thermal field (absolute degree) in the vertical section of the exhaust hood 


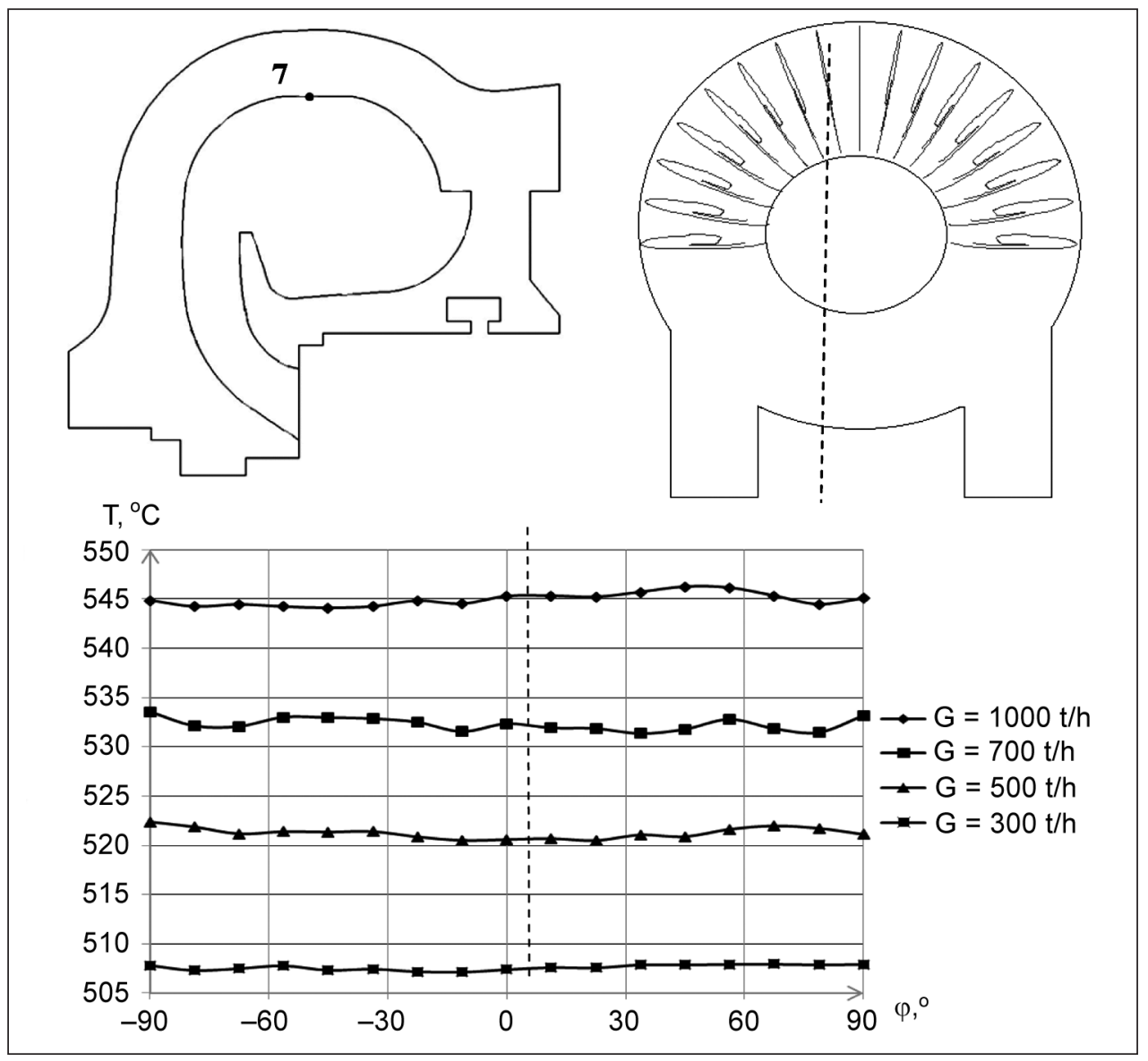

Fig. 7. The temperature distribution in the circumferential direction on the inner surface of the exhaust hood at the nominal and underloading turbine regimes

\section{CONCLUSIONS}

The uses of modern modeling methods of thermal and gas-dynamic processes based on the solving of direct heat transfer problems allow to identify heat transfer conditions in different elements of the turbine. These methods have high effectiveness at modeling processes in the exhaust hood of high-pressure cylinders of steam turbines.

The uneven distribution of temperature in the solid body of the exhaust hood requires making investigations of thermal stress conditions. For this purpose the inverse heat transfer problem will be solved based on the results of presented investigations. After that the heat transfer coefficients on inner surfaces of the exhaust hood will be defined which will be used like boundary conditions in thermal stress investigations.

The results of this work have shown that next investigations of thermal and gas-dynamic processes in the exhaust hood on varying conditions of operations are necessary, especially on starting and low-consumption regimes.

Received 10 August 2012 Accepted 11 December 2012

\section{References}

1. Dejch M. E., Zarjankin A. E. The Gas-dynamics of Diffusers and Exhaust Hoods of Turbines. Moscow: Energy, 1970. 384 p. (in Russian).

2. Schegljaev A. V. The Steam Turbines. Moscow: Energy, 1976. 368 p. (in Russian).

3. Subotin V. G., Levchenko E. V., Shvetsov V. L., Shubenko O. L., Tarelin A. O., Subotovich V. P. The Construction of Steam Turbine of New Generation with Power 325 MW. Kharkiv: Folio, 2009. 256 p. (in Ukrainian).

4. Menter F. R. Two-equation eddy-viscosity turbulence models for engineering applications. AIAA Journal. 1994. Vol. 32. No. 8. P. 1598-1605.

5. Fletcher K. The Computation Methods in Fluid Dynamics. Moscow: Mir, 1991. Vol. 1. 502 p., Vol. 2. 552 p. (in Russian). 
Svitlana Alyokhina, Olha Simbirska

\section{ŠILUMOS IR DUJŲ DINAMIKOS PROCESŲ GARO TURBINOS IŠMETIMO BLOKE MODELIAVIMAS}

\section{Santrauka}

Eksploatacijos saugumas bet kuriame turboenergetiniame įrenginyje priklauso nuo pagrindinių jo konstrukcinių elementų funkcionavimo, darbo efektyvumo ir patikimumo. Jiems nustatyti reikia naudotis moderniais turbinų įrengimų - konstrukcijų - tyrimo ar testavimo šiluminėse (TEC) ir kogeneracinèse jegainėse naudojamais metodais. Tai yra neįmanoma be išsamaus šilumos ir dujų dinamikos procesų ištyrimo.

Šiame darbe šilumos ir dujų dinamikos procesų tyrimas buvo vykdomas garo turbinos išmetimo bloke (gaubte). Buvo naudojamas jungtinio šilumos mainų uždavinio skaitmeninis sprendimas. Šis metodas leido nustatyti garo ir bloko - kieto gaubto garo šilumos ir garo greičių - lauką. Tyrimo rezultatai bus panaudoti skaičiuojant atvirkštinius šilumos mainų uždavinius siekiant nustatyti šilumos mainų koeficientus ant išmetimo gaubto vidinių paviršių.

Raktažodžiai: garo turbinos išmetimo blokas, jungtinis šilumos mainų uždavinys, šilumos ir dujų dinamikos procesai
Светлана Алёхина, Ольга Симбирская

\section{МОДЕЛИРОВАНИЕ ТЕПЛОВЫХ И \\ ГАЗОДИНАМИЧЕСКИХ ПРОЦЕССОВ В ВЫХОДНОМ ПАТРУБКЕ ПАРОВОЙ ТУРБИНЫ}

\section{Резюме}

Безопасность ээксплуатации любой турбоустановки зависит от эффективности и надежности работы ее основных конструктивных элементов. Для этого необходимо использование современных подходов и методов проектирования турбинного оборудования теплоэлектростанций и теплоэлектроцентралей, что осуществляется с помощью тщательного исследования тепловых и газодинамических процессов.

В данной работе было выполнено исследование тепловых и газодинамических процессов в выходном патрубке паровой турбины. Использовалось численное решение сопряженной задачи теплообмена. Такой подход позволил определить тепловое поле пара и металла корпуса, а также поле скоростей пара. Результаты исследования могут быть использованы при решении обратной задачи теплообмена для определения коэффициентов теплоотдачи на внутренней поверхности выходного патрубка.

Ключевые слова: выходной патрубок паровой турбины, сопряженная задача теплообмена, тепловые и газодинамические процессы 